Kamil Minkner

Uniwersytet Opolski

\title{
Metateoretyczne uwagi do koncepcji polityczności Chantal Mouffe w kontekście jej ideologicznych uwikłań
}

DOI: $10.19195 / 1643-0328.22 .4$

Słowa kluczowe: polityczność, agonizm, dyskurs, teoria konfliktu, metateoria

\section{Wprowadzenie}

Wśród podejść teoretycznych odnoszących się do konfliktów politycznych koncepcja polityczności Chantal Mouffe wydaje się jedną z częściej komentowanych. Perspektywa, którą Mouffe wypracowuje od lat 80. XX w. (początkowo wspólnie z Ernestem Laclauem), opiera się na założeniu, iż antagonizmy społeczne i wynikające z nich konflikty są nie tylko nieusuwalne, ale okazują się wręcz konstytutywną przesłanką istnienia każdego społeczeństwa ${ }^{1}$. Zdaniem Mouffe konflikty można najbardziej skutecznie regulować poprzez instytucje polityczne pod warunkiem jednak, iż dążyć się będzie do ich radykalnego spluralizowania. Prawdziwie demokratyczny system nie tłumi napięć, ale pozwala na artykulację potrzeb różnych grup społecznych. Dzięki temu możliwe będzie przekroczenie stosunków wrogości w relacjach między zantagonizowanymi podmiotami i wejście na poziom agonistyczny. Ta sytuacja nie eliminuje fundamentalnego antagonizmu (podmioty mają odmienne pozycje i perspektywy postrzegania rzeczywistości), ale oznacza, iż przeciwnicy nie odbierają sobie prawa do uczestnictwa w demokratycznej debacie i wzajemnie uznają swoją wolność i równość 2 .

Oryginalnym wkładem koncepcji Laclaua i Mouffe było uznanie, że antagonizmy są, paradoksalnie, obecne poprzez negację, poprzez niemożność ukonstytuowania się społeczeństwa jako zwartej całości ${ }^{3}$. W swoich samodzielnych pracach ten fundamentalny poziom sprzeczności Mouffe określa mianem polityczności, twierdząc, że wykracza on

${ }^{1}$ Przekrojowe, a przy tym klarowne omówienie teoretycznych założeń koncepcji agonistycznej można odnaleźć w: Ch. Mouffe, Agonistyka. Polityczne myślenie o świecie, Warszawa 2015, s. 17-32.

2 Ch. Mouffe, Paradoks demokracji, Wrocław 2005, s. 119.

3 E. Laclau, Ch. Mouffe, Hegemonia i socjalistyczna strategia. Przyczynek do projektu radykalnej polityki demokratycznej, Wrocław 2007, s. 131-137. 
poza politykę, przenicowując wszelkie możliwe rejestry rzeczywistości społecznej ${ }^{4}$. Co istotne, społeczne antagonizmy nigdy nie są nam dane bezpośrednio, ale ujawniają się poprzez skonfliktowane $\mathrm{z}$ sobą dyskursy. W analizie tych form władzy i wiedzy badacze zajmują się dyskursywną konstrukcją ideologiczno-politycznych granic oraz dychotomizacją przestrzeni społecznych ${ }^{5}$. W związku z tym w odniesieniu do całego podejścia pojawiają się nazwy typu „dyskursywna koncepcja władzy” czy „poststrukturalistyczna teoria dyskursu"6. Wybór ten wydaje się zasadny szczególnie w odniesieniu do pisarstwa Laclaua. Natomiast Mouffe w swoich samodzielnych pracach wykorzystuje pojęcie dyskursu, ale go nie problematyzuje. Zajmuje się raczej budową konfliktowo rozumianej koncepcji polityczności, której ważnym aspektem jest agonistyczny model radykalnej demokracji ${ }^{7}$.

Ze względu na wyrafinowanie wywodów przywołane na początku twierdzenia, bez względu na ich ocenę, mogłyby się wydawać typowymi rozważaniami, jakich sporo w teorii polityki, gdyby nie fakt, że mamy do czynienia z podejściem ideologicznie i politycznie uwikłanym. Zarówno Laclau, jak i Mouffe zawsze podkreślali, że ich koncepcja stanowi zbiór refleksji teoretycznych, które mają umożliwić praktyczne zmiany polityczne w duchu lewicowym. W związku z tym pojawia się kluczowy dla moich dalszych rozważań problem: czy (i dlaczego) za naukowe można uznać podejście tak jawnie ideologiczne? Należy jednocześnie zauważyć, że w pracach referujących koncepcję polityczności Mouffe problem ten w zasadzie nie występuje; zwolennicy koncepcji po prostu ją akceptują, a przeciwnicy odrzucają. Brakuje jednak refleksji nad relacjami między komponentami poznawczymi i ideologicznymi.

W artykule przyjmuję ogólne założenie, iż nauki i ideologii nie można od siebie w pełni odseparować. Oznacza to, iż nauka (szczególnie społeczna) opiera się często na ideologicznych założeniach, ale i ideologia posiada wartość poznawczą. Konkretyzując to założenie dla potrzeb niniejszych rozważań, uznaję, iż ideologiczne uwikłania danej koncepcji nie powinny dezawuować jej wiarygodności naukowej, o ile spełnia ona określone kryteria. Najbardziej użyteczna do ich omówienia wydaje mi się nie optyka sprawozdawczo-referująca, która po prostu streszcza daną koncepcję, ale metateoretyczna. Metateorię pojmuję tu w kategoriach części metawiedzy politologicznej, a więc refleksji nie tyle nad przedmiotem badania, ile nad procesem budowania wiedzy; $w$ tym przypad-

${ }^{4}$ Szerzej na temat różnych sposobów rozumienia pojęcia polityczności, w tym ujęcia agonistycznego, zob. w: K. Minkner, Główne problemy konceptualizacji pojęcia polityczności, „Studia Politologiczne” 37, 2015, s. 50-74.

${ }^{5}$ Fragment wstępu napisanego przez Laclaua do książki: Discourse Theory and Political Analysis: Identities, Hegemonies and Social Change, red. D. Howarth, A.J. Norval, Y. Stavrakakis, Manchester 2000, s. XI.

6 Zob. np. W. Marzec, Poststrukturalistyczna teoria dyskursu i empiryczne badania społeczne, „Praktyka Teoretyczna" 2011, nr 4, s. 185-198.

7 Uważa tak pośrednio sama Mouffe. W wywiadzie z jej udziałem, który jest integralną częścią książki Agonistyka, twierdzi ona, że koncepcja wypracowywana z Laclauem na temat hegemonii była określana jako „teoria dyskursu”. Jak sama zauważa, jej późniejsze prace, które powstały pod wpływem rozważań Schmitta nad politycznością, przyczyniły się do wypracowania agonistycznego modelu demokracji. Z tego powodu to pojęcia „agonizm” i „polityczność” okazują się kluczowe. Por. Ch. Mouffe, Agonistyka..., s. 133-148. 
ku teoretycznej ${ }^{8}$. Wyłuszczając już na początku tekstu główne tezy ujęcia polityczności Mouffe, chciałem podkreślić, że nie zawartość koncepcji będzie dla mnie najważniejsza; to raczej punkt wyjścia do analizy jej uwarunkowań, uwikłań (np. ideologicznych), referencji, form wywodów, struktury poznawczej, sposobów obecności w dyskursie naukowym oraz odniesień (krytycznych i aprobatywnych) do innych podejść. W tym widzę rolę teoretyków polityki, którzy, odnosząc się do danej koncepcji, winni problematyzować na głębokim poziomie jej status poznawczy. Głównym celem poniższych rozważań jest tego typu analiza na przykładzie koncepcji polityczności Chantal Mouffe.

Moje zamierzenia nie ograniczają się jednak do samej koncepcji Mouffe. Ponieważ w teorii polityki sporo jest podejść, które są syndromem elementów teoretycznych, filozoficznych i ideologicznych, potrzebne są sprawdzone sposoby ich weryfikacji. Zakładam, że koncepcja polityczności Mouffe może stanowić pretekst do wysondowania tego typu kryteriów. Nie chodzi o to, żeby dzięki temu naiwnie oddzielać teorie naukowe od spekulacji ideologicznych albo żeby aptekarsko szacować, „ile jest” ideologii w danej koncepcji. Chodzi raczej o zrozumienie roli komponentów ideologicznych w ramach refleksji teoretycznej oraz o sposoby ich wartościowego poznawczo przepracowywania i uteoretyzowania, a tym samym pochylenie się nad tym, jak zawartość ideologiczna okazuje się integralną częścią struktury poznawczej.

W tekście omawiam koncept agonizmu i polityczności przede wszystkim na podstawie prac Chantal Mouffe. Refleksje autorstwa Ernesta Laclaua przywołuję w celu uwypuklenia niektórych wywodów. Selekcja ta wynika w dużej mierze z ograniczeń przestrzennych krótkiego tekstu naukowego i generalnych podobieństw teoretycznych pomiędzy dwójką wspomnianych badaczy ${ }^{9}$.

\section{Ideologiczne uwikłania koncepcji polityczności Chantal Mouffe}

Zarówno Mouffe, jak i Laclau zaliczani są do lewicowego środowiska tzw. postmarksizmu, które nigdy nie stanowiło jakiegoś jednolitego podejścia. Oprócz Laclaua czy Mouffe odnajdujemy tu takich badaczy, jak Judith Butler, Slavoj Žižek, Tony Bennet, Richard Wolf, John Frow. Bez względu na różnice szczegółowe wszyscy oni dokonali rewizji klasycznego marksizmu, rezygnując z priorytetowego znaczenia walki klasowej i instancji

${ }^{8}$ M. Karwat, Metawiedza, esencja, forma, pragmatyka - cztery płaszczyzny badań teoriopolitycznych, [w:] Podejścia badawcze i metodologie w nauce o polityce, red. B. Krauz-Mozer, P. Ścigaj, Kraków 2013, s. 52, 56-59.

${ }^{9}$ Niektórzy badacze zwracają uwagę na różnice pomiędzy Mouffe i Laclauem. Jak twierdzi Mark A. Wenman, Laclau stara się uprzywilejować to, co uniwersalne, względem tego, co partykularne (nawet jeżeli wie, że uniwersalnie rozumiane społeczeństwo jako pewna całość jest niemożliwe do ustanowienia przez jeden partykularny podmiot). W ten sposób przeciwstawia się etyczno-politycznej koncepcji Mouffe, której myślenie o polityce zdominowane jest przez konieczność ekspresji wielości partykularnych „koncepcji dobra”. Za: K. Morawski, „Niemożliwość społeczeństwa”. Analiza postmarksistowskiego stanowiska Ernesta Laclaua, „Zeszyty Naukowe Towarzystwa Doktorantów UJ. Nauki Humanistyczne, Kierunki badawcze w filozofii” II, 2011, nr 3, s. 29-30. 
ekonomicznej jako głównej determinanty życia społecznego. Sięgając do dorobku strukturalisty Louisa Althussera oraz poststrukturalisty Michela Foucaulta, przedstawiciele postmarksizmu dostrzegli bardziej pluralistyczne oblicze kapitalizmu, a przede wszystkim podziały społeczne o charakterze płciowym, etnicznym czy rasowym, które stoją u podstaw zróżnicowanych żądań poszczególnych grup. Z jednej strony odarli marksizm $\mathrm{z}$ potencjału totalitarnego, a $\mathrm{z}$ drugiej $-\mathrm{z}$ jego odniesień do humanistycznej wspólnoty wszystkich klasowo uciemiężonych grup ${ }^{10}$.

Konkretyzując powyższe założenia w Hegemonii i socjalistycznej strategii (pierwsze wydanie - 1985 r.), jednym z najważniejszych dzieł postmarksistowskich, Laclau i Mouffe postulowali konieczność odnowy lewicy poprzez zerwanie z klasizmem, czyli wiarą, iż klasa robotnicza stanowi uprzywilejowany podmiot kontrhegemoniczny, dzięki któremu znikną także inne formy opresji. Jak dowodzili, pomiędzy antyseksizmem i antyrasizmem a antykapitalizmem nie ma żadnego koniecznego powiązania. Lewicowa polityka winna zmierzać do narzucenia tego typu powiązań, a następnie poprzez wypracowanie logiki równoważności pomiędzy nimi przyczynić się do stworzenia kontrhegemonicznego bloku, dzięki czemu poszczególne walki otrzymają nowe znaczenie i skonsolidowanie. Konstrukcja taka nigdy nie będzie do końca stabilna, ponieważ poszczególne walki są autonomiczne i nie mają żadnego trwałego oparcia w jednym podmiocie, ale zarazem nie ma dla nich żadnych ograniczeń, ponieważ poszczególne sprzeczności można i należy ujawniać w każdej możliwej przestrzeni życia społecznego (np. instytucje prawne, edukacja, stosunki pracy itd.) ${ }^{11}$. Aby było to możliwe, należy zerwać z esencjalistycznie rozumianą Lewicą i Prawicą, które mają raz na zawsze ustalone desygnaty. Stawką tej walki jest wykreowanie autentycznej alternatywy, żeby ludzie mieli wybór, a nie musieli głosować ciągle na te same programy ${ }^{12}$. W poszczególnych pracach Mouffe padały także bardziej szczegółowe postulaty polityczne. W Paradoksie demokracji stara się ona zastosować swoje teoretyczne dociekania do omówienia konkretnych problemów polityki społecznej w duchu, jak to nazywa, postsocjaldemokratycznym. Uznając, że najważniejszym problemem staje się narastające bezrobocie, postuluje m.in. skrócenie czasu pracy przy czynnej redystrybucji pomiędzy pracownikami otrzymującymi stałą pensję oraz przyznanie tzw. dochodu minimalnego dla najbardziej potrzebujących ${ }^{13}$.

Polityczne uwikłania rozważań Mouffe i Laclaua obejmują nie tylko ich cele, ale wiążą się także $\mathrm{z}$ argumentacją, która opiera się w wielu miejscach na ustaleniach lewicowych badaczy. Za najważniejszych z nich należy uznać Antonia Gramsciego oraz Louisa Althussera. Obaj wpisywali się w tradycję marksistowską, ale zarazem znacząco ją przeformułowali. Z racji braku miejsca skupię się na nawiązaniach do Gramsciego, które dla agonistów okazały się bardziej istotne.

10 P. Goldstein, Post-Marxist Theory: An Introduction, New York 2005, s. 2-8.

11 E. Laclau, Ch. Mouffe, op. cit., s. 185-202.

12 Ludzie potrzebuja alternatywy. Z Chantal Mouffe i Ernesto Laclauem rozmawiaja Maciej Gdula, Julian Kutyła i Adam Ostolski, http://www.krytykapolityczna.pl/Nr7-82005/Ludziepotrzebujaalternatywy/menuid-1.html (dostęp: 2 października 2016).

13 Ch. Mouffe, Paradoks demokracji..., s. 141-142. 
To właśnie od Gramsciego Mouffe i Laclau zaczerpnęli kluczowy dla ich rozważań koncept hegemonii. Oznacza ona taki typ panowania, którego władza nie narzuca odgórnie, ale jest on współkreowany poprzez podporządkowane władzy jednostki internalizujące wartości grup dominujących.

Dąży się nawet do stworzenia pozorów, że siła oparta jest na aprobacie większości, wyrażającej się przez tak zwane organa opinii publicznej — prasę i stowarzyszenia - których ilość w pewnych sytuacjach zostaje w tym celu właśnie sztucznie zwiększona ${ }^{14}$.

Z taką sytuacją zdaniem Laclaua i Mouffe mamy do czynienia we współczesnej demokracji liberalnej. Powszechnie uznano, że jest to najbardziej uniwersalna forma systemu politycznego, która spowodowała zakończenie konfliktów ideologicznych. A tymczasem tego typu postpolityczna argumentacja skrywa, iż w sercu każdego porządku politycznego są napięcia wynikające $\mathrm{z}$ antagonizmów. $\mathrm{Z}$ tego powodu hegemonia nigdy nie jest do końca stabilna. Każdy porządek dominujący zawsze musi zakładać opór i niestabilność. Laclau i Mouffe w swoich książkach i wywiadach wielokrotnie podkreślają, w duchu Gramsciego, napięcie pomiędzy dominacją formacji hegemonicznej a jej podatnością na zakwestionowanie, a tym samym antagonistyczny charakter porządku dominującego. Zdaniem Mouffe

każda społeczna przedmiotowość ma zasadniczo polityczną naturę i musi zawierać ślady wykluczenia rządzącego jej konstytucją. Właśnie ów punkt zbieżności — czy może obustronnego znoszenia się — pomiędzy przedmiotowością i władzą mamy na myśli, mówiąc o „hegemonii”15.

Dla przedstawicieli koncepcji agonistycznej ważne jest również dowartościowanie przez Gramsciego nadbudowy (symbole, wartości, kultura, moralność). Ma ona wręcz autonomię, ponieważ to właśnie na jej terenie toczą się walki,

dopóki jedna z partii lub jakieś ich połączenie nie zwycięży i nie opanuje całego terenu społecznego, doprowadzając tym samym nie tylko do jedności dążeń ekonomicznych i politycznych, lecz także do jedności intelektualnej i moralnej ${ }^{16}$.

Kluczowe znaczenie ma w tym względzie ideologia. Gramsci był tym badaczem, który pokazał jej siłę w scalaniu antagonistycznych bloków historycznych walczących o narzucenie porządku hegemonicznego. Jak komentują Laclau i Mouffe, ideologia w rozumieniu Gramsciego uzyskiwała szeroki, dynamiczny i relacyjny charakter, a co ważne - nie była postrzegana wyłącznie jako jakaś determinująca siła sprawcza, działająca „W imieniu" władzy ${ }^{17}$.

Laclau i Mouffe uznają także wkład Gramsciego w podkreślaniu, iż hegemonia nie chce się jawić ideologicznie czy partykularnie, a uniwersalnie i naturalnie. Jak twierdził Gramsci, każda warstwa społeczna ma swój potoczny rozsądek. Chociaż na obszarze tym dochodzi do nieustannych naporów ze strony różnych rejestrów ideologicznych,

14 A. Gramsci, Nowoczesny książe, Warszawa 2006, s. 65.

15 Ch. Mouffe, Paradoks demokracji..., s. 116-117.

16 A. Gramsci, op. cit., s. 33.

17 Zob. uwagi autorów dotyczące znaczenia Gramsciego dla teorii hegemonii: E. Laclau, Ch. Mouffe, op. cit., s. 71-79. 
to ulegają one naturalizacji w postaci rozpowszechnionych poglądów na świat i ludzi ${ }^{18}$. Wykorzystując tego typu aparaturę, Mouffe twierdzi, iż stabilizacja demokracji liberalnej, jak każdej hegemonii, polega na wykreowaniu efektu zdrowego rozsądku, który jest powszechnie podzielany ${ }^{19}$. W rezultacie to na tym polu, zdaniem przedstawicieli tradycji gramsciańskiej, dochodzi do kluczowych konfliktów politycznych ${ }^{20}$.

Pomimo wielu lewicowych inspiracji ze strony Gramsciego można ten ideologiczny potencjał zawarty w pracach Mouffe i Laclaua zrównoważyć poprzez wartość poznawczą ich koncepcji. Co więcej, twierdzę, że ideologiczna zawartość nie tyle nie przeczy wartości poznawczej, ile wręcz ją współtworzy. Istotne jest tu uchwycenie trzech ogólnych przesłanek. Po pierwsze, nauki polityczne od początku swego istnienia były uwikłane ideologicznie, a teorie, które miały tylko coś wyjaśniać, nierzadko stanowiły oręż w propagowaniu określonych poglądów. W zasadzie ciężko znaleźć podejście, któremu by nie przypisywano tego typu zarzutów. Przywołać tu można zarówno przypadki oczywiste, jak konfliktowe koncepcje Karola Marksa czy Carla Schmitta, jak i mniej jednoznaczne. Już u zarania politologii uznawano, że niektóre koncepcje demokracji są tak naprawdę wyrazem opowiadania się za jakimś konkretnym jej wariantem ${ }^{21}$. Oceny tego typu odnosiły się także do najbardziej klasycznych teorii politologicznych. Czasami te same ideologiczne zarzuty formułowano pod adresem zupełnie sprzecznych względem siebie koncepcji. W ten sposób zakładano, że zarówno funkcjonalizm, jak i dialektyczna teoria konfliktu Ralfa Dahrendorfa reprodukują status quo demokracji liberalnej22.

Drugim czynnikiem pozwalającym na odpowiednią weryfikację zawartości ideologicznej koncepcji polityczności Mouffe jest sfera postulatów politycznych. O ile Gramsci wierzył w zwycięstwo socjalizmu, o tyle Mouffe i Laclau wierzą w zwycięstwo lewicowego dyskursu w ramach demokracji liberalnej. Ten demokratyczny horyzont jest dla nich nieprzekraczalny. Postmarksizm, jaki propagują, jest oczywiście promocją jakiegoś ideowego punktu widzenia, ale mieszczącego się w ramach demokratycznej debaty politycznej i naukowej. Mouffe określa nawet bliskie jej środowisko agonistów jako „lewicowych liberałów”, z których nikt nie kwestionuje wkładu liberalizmu w rozwój

18 A. Gramsci, Zeszyty filozoficzne, Warszawa 1991, s. 513-514.

19 Ch. Mouffe, The Return of the Political, London-New York 1993, s. 53.

20 Ch. Mouffe, Polityczność. Przewodnik Krytyki Politycznej, Warszawa 2008, s. 33.

21 Szerzej na ten temat piszę w: K. Minkner, Tradycyjny instytucjonalizm i jego znaczenie dla nauk politycznych, „Historia i Polityka” 2015, nr 13, s. 9-29.

22 Klasyczny funkcjonalizm określa się czasami jako teorię naukową skażoną konserwatyzmem lat 50. XX w. i będącą w istocie formą naukowej racjonalizacji i legitymizacji ówczesnego układu sił politycznych. Zob. np. B. Berberoglu, An Introduction to Classical and Contemporary Social Theory: A Critical Perspective, Oxford 2005, s. 79 n. Uznawana za empirycznie wiarygodną teoria konfliktu R. Dahrendorfa również bywa określana jako ideologiczna. Autorowi zarzucono liberalne nachylenie oraz uczynienie z władzy przeźroczystej siły determinującej strukturę społeczną w oderwaniu od struktury ekonomicznej. Z kolei Janusz Mucha podkreślał, że teoria Dahrendorfa nie dotyczy tak naprawdę konfliktów strukturalnych, które mogłyby obalić system, i dlatego również wspiera status quo. Zob. szerzej: D. Pels, Property and Power in Social Theory: A Study in Intellectual Rivalry, London-New York 1998, s. 168; J. Mucha, Konflikt i społeczeństwo. Z problematyki konfliktu społecznego we współczesnych teoriach zachodnich, Warszawa 1978, s. 239-241. 
nowoczesnej demokracji ${ }^{23}$.Zdaniem Stuarta Sima postmarksizm to nurt, który narodził się z rozczarowania, ale wyrażał optymistyczną wiarę w polityczną przyszłość wolną od Marksowskiej ortodoksji. Zrywał z podporządkowaniem jednostki systemowi na rzecz pluralizmu, podkreślania różnic, sceptycyzmu względem władzy oraz celów nowych ruchów społecznych ${ }^{24}$. Mouffe zwraca zarazem uwagę, iż środowisko lewicowych liberałów wcale nie jest jednolite. Krytykuje przykładowo „postmodernistyczny liberalizm mieszczański” neopragmatysty Richarda Rorty’ego za to, że nie dostrzega on różnic między liberalizmem politycznym i ekonomicznym oraz pomiędzy demokracją i liberalizmem, które dla Mouffe uległy powiązaniu jedynie sytuacyjnemu. Mouffe obawia się, że prowadzić to może do apologii amerykańskich instytucji politycznych, a tym samym nie pozostawi już pola do żadnej konstruktywnej krytyki. Zdaniem Mouffe liberalizm, w jaki wierzy Rorty, prowadzić może do kolejnego stadium depolityzacji, a więc pozornego zaniku konfliktów, ponieważ opiera się on na naiwnej wierze, że demokracja liberalna będzie się rozprzestrzeniać wraz z postępem ekonomicznym, stopniowymi reformami i małymi kompromisami wokół problemowych spraw ${ }^{25}$.

Trzecia płaszczyzna rozpatrywania relacji między elementami ideologicznymi i poznawczymi w ramach danej koncepcji ma charakter naukowy. Na tej podstawie można orzec, że uwikłania ideologiczne nie są podstawą do odrzucenia danej koncepcji, a raczej wskazują na konieczność jej właściwego naukowego przepracowania i przyporządkowania. Mając na uwadze wyłuszczone ideologiczne odniesienia, wydaje się właściwe zaliczenie Laclaua i Mouffe w nurt nauki krytycznej. Myślenie tego typu było od XIX w. wymierzone $\mathrm{w}$ oświeceniowy optymizm zakładający, że procesy społeczne wykazują postęp, a nauka jest racjonalna, uniwersalna i neutralna. Tymczasem dla badaczy krytycznych wiedza naukowa okazuje się często narzędziem reprodukcji systemu (np. kapitalistycznego albo patriarchalnego $)^{26}$. Jedną z prominentnych postaci tej tradycji był również Gramsci, dla którego nauka była nie tylko odkrywaniem prawdy. Krytykował on pozytywistyczny model wiedzy, który jego zdaniem zawsze wspiera jakieś społeczne kompromisy, ale domagał się, aby poprzez naukę zaangażowaną w proces konstruowania alternatywnej interpretacji rzeczywistości wypracować nową hegemonię $e^{27}$. Na płaszczyźnie naukowej szczególnie wartościowe okazują się rozważania metateoretyczne, które wiążą się z analizą paradygmatycznych założeń danej koncepcji oraz jej funkcjonowania w dyskursie naukowym. Spełnienie w tym względzie odpowiednich kryteriów może skłaniać do uznania wysokiej wartości poznawczej danej ideologicznie uwikłanej koncepcji. Nie pomimo jej ideologiczności, ale z jej uwzględnieniem. Przedstawienie i analiza wzmiankowanych kryteriów to właściwy cel dalszych rozważań.

23 Ch. Mouffe, Wyzwanie Schmitta, [w:] Carl Schmitt. Wyzwanie polityczności, red. eadem, Warszawa 2011, s. $10-11$.

24 S. Sim, Post-Marxism. An Intellectual History, London-New York 2001, s. 3.

25 Ch. Mouffe, The Return of the Political..., s. 10.

26 Por. J.H. Turner, Struktura teorii socjologicznej. Wydanie nowe, Warszawa 2004, s. 631-632.

27 L. Salamini, The Sociology of Political Praxis: An Introduction to Gramsci's Theory, London-New York 2014, s. 49-50. 


\section{Założenia ontologiczne i epistemologiczne}

Rekonstrukcja założeń ontologicznych i epistemologicznych każdego podejścia naukowego winna być zawsze pierwszym krokiem jego naukowej weryfikacji. Koncepcja polityczności Mouffe jest w tym względzie dość czytelna, gdyż sama autorka, zgodnie z przesłaniem nauki krytycznej, otwarcie deklaruje swoje metateoretyczne stanowisko badawcze. Twierdzenia agonistycznej teorii konfliktu wiążą się ściśle z głównymi założeniami poststrukturalizmu i różnymi ponowoczesnymi ujęciami krytykującymi takie wartości naukowe, jak naturalizm, esencjalizm, uniwersalizm i racjonalizm, które w naukach społecznych, w tym politycznych, uobecniły się w pełni w modelu pozytywistycznym. Pod względem ontologicznym podejście poststrukturalne opiera się na antynaturalizmie, co oznacza, że nie istnieje żadna rzeczywistość sama-w-sobie, niezależna od podmiotu poznającego. Pod względem epistemologicznym przyjmuje się interpretacjonistyczne założenie, iż rzeczywistość ma charakter społecznie skonstruowany ${ }^{28}$.

W przypadku Mouffe, jak również Laclaua, ontologia i epistemologia łączą się z sobą, ponieważ procesy konstruowania rzeczywistości i możliwości jej rozumienia odbywają się zawsze w ramach dyskursu ${ }^{29}$. Jak twierdzi Ernesto Laclau, pojęcie to wiąże się z

transcendentalnym zwrotem w nowożytnej filozofii [i wyraża - KM] w typie analizy skierowanej przede wszystkim nie na fakty, lecz na warunki ich możliwości. Zgodnie z podstawową hipotezą dyskursywnego podejścia sama możliwość postrzegania, myślenia i działania zależy od ustrukturowania pewnego sensownego pola, które poprzedza każdą faktyczną bezpośredniość ${ }^{30}$.

Poststrukturalny interpretacjonizm promujący ujmowanie polityki i polityczności w kategoriach narracji i dyskursów wiąże się z szerszym, tzw. językowym, zwrotem w filozofii. Jedną z podstawowych jego cech — jak twierdzi Jerzy Topolski — jest to, że język, dyskurs, narracje i różne znaczenia przestają być neutralnymi mediami w obiektywnym opisywaniu rzeczywistości, ale traktowane są ,jako narzędzie niezbędne do konstruowania obrazów świata (»możliwych światów«), nad którymi posługujący się nim może panować tylko częściowo" ${ }^{31}$. Dla poststrukturalistów oznacza to, że znaczenie jest jednym z najważniejszych przedmiotów konfliktu politycznego. Przy czym, co oczywiste, nie chodzi tu o żonglerkę pojęciami, ale o to, jaka perspektywa poznawcza zostanie uznana za obowiązującą.

Nadawanie znaczeń w sposób antagonistyczny — puentuje założenia postmarksizmu Tadeusz Buksiński — oznacza polityczne konstruowanie społecznego porządku, czyli obiektywnego systemu różnic. Te obszary walki tworzą przestrzenie polityczne ${ }^{32}$.

28 Wyjaśnienie podstawowych paradygmatów w naukach politycznych pod względem ontologicznym i epistemologicznym można znaleźć w: D. Marsh, P. Furlong, Skóra, a nie sweter: ontologia i epistemologia w politologii, [w:] Teorie i metody w naukach politycznych, red. D. Marsh, G. Stoker, Kraków 2006, s. 17-40.

29 Por. W. Marzec, op. cit., s. 187.

30 E. Laclau, Dyskurs, [w:] Przewodnik po współczesnej filozofii politycznej, red. R.E. Godin, F. Petit, Warszawa 2002, s. 555.

31 J. Topolski, Linguistic turn w historiografii. Ze wspótczesnej filozofii humanistyki, „Studia Politologiczne" 8, 2004, s. 217.

32 T. Buksiński, Współczesne filozofie polityki, Poznań 2006, s. 232. 


\section{Wiktor Marzec podkreśla, że}

dla poststrukturalistów bliska jest wizja Foucaulta, iż dany dyskurs jest paradoksalnie stabilny w swoim rozproszeniu, a tym samym zwracają oni uwagę na potencjalną płynność tożsamości elementów pola dyskursywnego. [...] Podmioty (indywidualne i zbiorowe) nie mają stałej, zdeterminowanej w jakiś określony sposób tożsamości ${ }^{33}$.

Należy jednak zaznaczyć, że samo rozumienie dyskursu jest w poststrukturalizmie zróżnicowane. Lotar Rasiński zwraca uwagę, że podejścia Laclaua i Mouffe oraz teorii dyskursu Foucaulta różnią się pojmowaniem praktyk dyskursywnych i niedyskursywnych, a więc wiedzy i władzy. Bez względu na kierunek determinacji, a nawet wzajemne wpływy, Foucault ujmuje oba porządki rozdzielnie i wiele uwagi w swoich pracach przeznacza na ich porównywanie. Tymczasem Laclau i Mouffe twierdzą, że organizacja społeczeństwa czy instytucje władzy, które dla Foucaulta należą do struktur niedyskursywnych, są częścią antagonistycznie rozumianych powiązań dyskursywnych ${ }^{34}$.

Wielu krytyków podejścia Mouffe i Laclaua, mając na uwadze tego typu opisy, uważa, że konflikty, które opisują, dotyczą jedynie sfery znaczeń i symboli, nie zaś twardego jądra polityki (interesy ekonomiczne, zasoby naturalne, siła militarna). Tymczasem omawiani autorzy twierdzą jedynie, że także „twarde fakty” mają swoją znaczeniową reprezentację. Jak piszą Mouffe i Laclau, trzęsienie ziemi jest faktem, ale to, czy przedstawi się je jako zdarzenia naturalne, czy np. efekt „gniewu bożego”, zależy już od dyskursu ${ }^{35}$. Proces artykulacji w ramach dyskursu odbywa się w warunkach antagonistycznego zderzenia podmiotów. „To od politycznych dyspozycji, interesów i przekonań zależne jest znaczenie wielu praktyk, na przykład stosowanie w medycynie metody in vitro, praktykowanie aborcji czy budowa autostrady na terenie Doliny Rospudy" ${ }^{36}$. Warto w tym względzie podkreślić podobieństwo tych refleksji z koncepcją dalekiego od poststrukturalizmu Carla Schmitta, który kilkadziesiąt lat przed przełomem językowym twierdził, iż wszelkie pojęcia polityczne są polemiczne. Same w sobie pozostaną puste semantycznie, jeżeli nie będzie wiadomo nie tylko, co oznaczają, ale i przeciw komu są stosowane (np. demokracja to system wymierzony w elity posiadające dawniej przywileje) ${ }^{37}$.

W pracach Laclaua i Mouffe na poststrukturalne założenia wskazuje się bezpośrednio, a wręcz czyni z nich rdzeń rozumienia konfliktu politycznego. Jak twierdzi Mouffe:

Perspektywa zainspirowana przez poststrukturalizm, która kładzie nacisk na nieredukowalną inność będącą zarówno warunkiem możliwości, jak i warunkiem niemożliwości każdej tożsamości, dostarcza znacznie lepszego schematu teoretycznego dla uchwycenia specyfiki nowoczesnej demokracji, niż czyni to stanowisko racjonalistyczne ${ }^{38}$.

33 W. Marzec, op. cit., s. 187.

34 L. Rasiński, Dyskursywna koncepcja władzy. Foucault i Laclau o dyskursie, podmiocie i władzy, „Principia” III, 2010, s. 177.

35 E. Laclau, Ch. Mouffe, op. cit., s. 115.

36 P. Przyłęcki, Założenia teorii dyskursu Ernesta Laclaua i Chantal Mouffe, „Przegląd Socjologiczny” 2013, nr 4, s. 10-11.

37 C. Schmitt, Teologia polityczna i inne pisma, Kraków 2000, s. 202-204.

38 Ch. Mouffe, Paradoks demokracji..., s. 52. 
Laclau tłumaczy, iż jedno z podstawowych pojęć poststrukturalnych, dekonstrukcja w rozumieniu Jacques’a Derridy, posiada polityczną logikę, gdyż artykułuje nierozstrzygalność na szerokim obszarze tego, co społeczne i polityczne, a zarazem domaga się choćby tymczasowych rozstrzygalności. W rezultacie, jak dowodzi Laclau, hegemonia wymaga dekonstrukcji, ponieważ bez niej społeczeństwo jawiłoby się jako zbiór relacji o charakterze naturalnym i koniecznym, podczas gdy jest tylko zbiorem praktyk dyskursywnych, które cechuje przypadkowość artykułowana w ramach porządku hegemonicznego. Jednocześnie dekonstrukcja wymaga hegemonii, by zbadać, jak znaczenie ulega stabilizacji ${ }^{39}$. Zarówno dla Laclaua, jak i dla Mouffe kluczowe okazuje się zaczerpnięte od Derridy pojęcie „konstytutywnego zewnątrz”. Pojęcie to wskazuje, że proces konstytuowania się każdej tożsamości jest zawsze oparty na wykluczeniu i ustanawianiu opartych na przemocy hierarchii opozycyjnych. „My” i „oni” to jednak nie odrębne, esencjalnie rozumiane antagonistyczne podmiotowości, ponieważ nie istnieje żadna tożsamość, która samoistnie by się konstruowała. Ten proces zawsze odbywa się na zasadzie różnicy i poprzez akty władzy. Dlatego każda społeczna obiektywność ma polityczną naturę, a „konstytutywne zewnątrz” wskazuje na ślady po ustanowieniu tej tożsamości i jednocześnie na elementy wykluczone, które są jej warunkiem koniecznym ${ }^{40}$.

Znaczenie założeń poststrukturalistycznych dla rozważań Mouffe i Laclaua okazuje się bardziej czytelne, kiedy zestawi się poststrukturalizm ze strukturalizmem. Przedstawiciele tej drugiej perspektywy założyli, że życie społeczne czy język są zdeterminowane przez głębokie struktury i relacje. Strukturalistyczna koncepcja Ferdinanda de Saussure’a zakłada, że znaczenie jest wypadkową relacji pomiędzy signifiant (element znaczący) i signifié (element znaczony) oraz ma charakter arbitralny. Komentując te założenia, postmodernista Jacques Derrida uznaje, że taka relacja musi się zawsze opierać na założeniu znaczonego transcendentnego (istniejącego niezależnie od znaku), które okazuje się gwarantem i możliwością wszelkiego znaczenia. Chcąc wykazać nieprawomocność tego rozumowania, Derrida opiera się początkowo na rozumowaniu de Saussure’a i twierdzi, że każde pojęcie „zostaje $\mathrm{z}$ istoty wpisane w łańcuch czy też system, w granicach którego odnosi się do innego pojęcia i innych pojęć za sprawą systemowej gry różnic" ${ }^{41}$. Następnie wprowadza swój neologizm „różnia”, który obejmuje zarówno różnice między znaczeniami, jak i permanentne odwlekanie znaczenia. Co więcej, to różnia, a nie znaczone transcendentne warunkuje różnice, a tym samym jest warunkiem wszelkiej pojęciowości. W rezultacie nie ma już żadnej pierwotnej obecności znaczonej, bo nie ma żadnej obecności poza znakami; znaczenie jest więc nierozstrzygalne, ponieważ jest uwikłane wyłącznie $\mathrm{w}$ językowy system różnic ${ }^{42}$. Właśnie to mają na myśli Mouffe i Laclau, kiedy mówią o możliwości redefiniowania bloku kontrhegemonicznego poprzez łańcuchy ekwiwalencji pomiędzy wytworzonymi w warunkach antagonistycznych różnymi tożsamościami (rasowymi, etnicznymi, płciowymi), które można dyskur-

39 E. Laclau, Deconstruction, Pragmatism, Hegemony, [w:] Deconstruction and Pragmatism, red. Ch. Mouffe, New York 2005, s. 56-62.

40 Ch. Mouffe, The Return of the Political..., s. 85, 141.

41 J. Derrida, Marginesy filozofii, Warszawa 2002, s. 37.

42 Zob. szerzej: J. Derrida, O gramatologii, Łódź 2011, s. 45, 81 n. 
sywnie powiązać i tym samym uzyskać dla nich nowe znaczenie. „Radykalna demokracja nie odnosi się zatem do jednego partykularnego podmiotu, ale do samego pogłębienia projektu radykalnej demokracji poprzez logikę ekwiwalencji”43.

Poststrukturalistyczne założenia paradygmatyczne pozwalają teoretykom agonizmu pomieścić bardzo zróżnicowany kompleks szczegółowych inspiracji i zająć się w związ$\mathrm{ku} z$ tym rozmaitymi problemami. Wynika to z dwóch powodów. Po pierwsze, poststrukturalizm w odróżnieniu od paradygmatu pozytywistycznego sproblematyzował fundujące go założenia, podczas gdy pozytywizm uznawał swoje założenia za przeźroczyste. To z kolei wymagało od poststrukturalistów bardzo pogłębionego programu teoretycznego, który na nowo przepracowywał wszystkie niedostrzegane dotąd fundamentalne problemy w nowym ujęciu. Po drugie, w przypadku poststrukturalizmu stosunki władzy ulegają oderwaniu od sfery polityki i rozpraszają się na wszelkie możliwe rejestry rzeczywistości społecznej: wiedzę, język, podmiotowość, życie codzienne, stosunki prywatne ${ }^{44}$. Z obu wymienionych powodów poststrukturaliści, tacy jak Mouffe, sięgali do tak, wydawałoby się, egzotycznych w stosunku do teorii polityki dyscyplin, jak psychoanaliza. Pozwoliła im ona na nowo przemyśleć status podmiotu politycznego w kategoriach konfliktowych. Zdaniem Mouffe włączenie psychoanalizy jest konieczne, ponieważ praktyki podmiotów politycznych opierają się nie na racjonalnym równoważeniu różnych interesów, jak chcieli propagatorzy postpolityki, ale na namiętnościach i emocjach. Mouffe szuka w tym względzie inspiracji w koncepcjach twórcy psychoanalizy, Zygmunta Freuda, przypominając, że pojmował on kulturę i społeczeństwo jako ciągle podatne na wewnętrzne napięcia, a wręcz na rozpad z powodu wrodzonego człowiekowi instynktu agresji. To dlatego społeczeństwo wymaga publicznych fantazji, z którymi emocjonalnie może się identyfikować, i kreuje na tej podstawie zbiorowe, czasowo spójne tożsamości. Przyczynia się to do wytworzenia kryteriów ekskluzji, według których wyznaczane są granice dla tych, którzy nie należą do „my”45. Za przykład takiej fantazji może służyć dyskurs nacjonalistyczny. Mouffe wykorzystuje także psychoanalityczne inspiracje kontynuatora Freuda, Jacques’a Lacana. Podmiotowość jego zdaniem uzyskuje się w ramach określonego dyskursywnego porządku symbolicznego, ale jest on zawsze niedomknięty, ukazując w ten sposób siłę Realnego, a więc tych pozycji, które nie poddają się symbolizacji. Z tego powodu podmiot jest w psychoanalizie zdecentrowany, pozbawiony swojej niezależności i reprezentowany w strukturze poprzez puste miejsce. Jest ono koniecznym warunkiem każdej tożsamości, która może zostać ukonstytuowana na podstawie określonych podmiotowych identyfikacji ${ }^{46}$. Identyfikacje te nie są jednak wyrazem określonych i świadomie deklarowanych interesów, ale są produktem antagonistycznych relacji w systemie.

Tytułem podsumowania tego fragmentu rozważań można stwierdzić, że wbrew temu, co się często zarzuca, poststrukturalizm, przynajmniej w wariancie propagowa-

${ }^{43}$ Ludzie potrzebuja alternatywy...

44 Por. Z. Melosik, Poststrukturalizm jako teoria życia społecznego (możliwości i kontrowersje), „Kultura Współczesna" 1997, nr 1, s. 57-71.

45 Ch. Mouffe, Polityczność..., s. 40.

46 Ch. Mouffe, The Return of the Political..., s. 76. 
nym przez Mouffe, nie jest jakimś rodzajem postmodernistycznego anarchizmu poznawczego. W swojej książce Powrót polityczności badaczka tłumaczy wręcz, że nie ma czegoś takiego, jak „postmodernizm”, który byłby jakimś zwartym paradygmatem. Istnieje ponowoczesna krytyka oświeceniowego uniwersalizmu i racjonalizmu, ale jej reprezentanci wykraczają poza krąg badaczy poststrukturalnych (np. Martin Heidegger, Hans-Georg Gadamer, tzw. późny Ludwig Wittgenstein, Jacques Lacan). Odcięcie się od postmodernizmu przez Mouffe objawia się również poprzez polemiki z jego przedstawicielami. Badaczka krytykuje chociażby Jeana-François Lyotarda, który twierdził, że skoro nie są już możliwe żadne wielkie narracje, rozumiane jako uniwersalistyczne i racjonalistyczne systemy idei, to odrzucenia wymaga również demokracja liberalna. Mouffe się z tym nie zgadza i twierdzi, że jej koncepcja jest zarówno modernistyczna, jak i ponowoczesna. Przynależy do modernizmu, bo chce zachować obowiązującą moc demokracji, ale jednocześnie chce zerwać z jej moralistycznym i esencjalnym uzasadnianiem, które prowadzą do sztucznego tłumienia problemów. Mouffe postuluje w tym względzie antyesencjalizm. Uznaje, że wszelkie struktury mają charakter przygodny, labilny, niezdeterminowany, co nie znaczy, że nie są one realnie odbierane przez jednostki ${ }^{47}$. Logika tego myślenia ujawnia się chociażby w ujęciu demokracji liberalnej Mouffe. Badaczka uznaje, że system ten opiera się na dwóch sprzecznych z sobą, a wcześniej wręcz zwalczających się porządkach, które w ramach określonych uwarunkowań zostały powiązane i znaturalizowane. Tymczasem ich powiązanie jest polityczne, a przez to obciążone antagonizmem ${ }^{48}$. Mouffe jest również przeciwniczką postulowanego jej zdaniem przez postmodernistów nieograniczonego pluralizmu bez granic. Jej zdaniem demokratyczne granice wyznaczane są przez zasady, które nie są wprawdzie uniwersalistyczne, ale zostały wynegocjowane przez wszystkich uznanych uczestników. Agonistyczna polityka nie ma więc obejmować wszelkich różnic, a jedynie te, które można wpisać w logikę demokratycznego porządku ${ }^{49}$.

\section{Struktura i forma wywodów teoretycznych oraz ich aplikacja}

Drugą po fundamentalnych założeniach paradygmatycznych płaszczyzną weryfikacji poznawczej ideologicznie uwikłanej koncepcji naukowej winna być próba opisania struktury i formy jej teoretycznych treści oraz ich uobecnienie w dyskursie naukowym. Z punktu widzenia klasycznej metodologii nauk społecznych koncepcje takie jak Mouffe są problematyczne $z$ dwóch powodów. Po pierwsze, brakuje im empirycznej weryfikacji; po drugie, ich ideologiczność sprawia, że mogą stanowić oręż w realizacji interesów określonych grup ${ }^{50}$. Uwzględnienie tych zastrzeżeń oznaczałoby jednak, że rangę wywodów o teoretycznej doniosłości mają wyłącznie spójne i empirycznie zweryfikowane sys-

\footnotetext{
${ }^{47}$ Ch. Mouffe, Radical democracy: modern or postmodern?, „Social Text” 1989, nr 21, s. 31-45.

48 Ch. Mouffe, Paradoks demokracji..., s. 22-23.

49 Ch. Mouffe, Polityczność..., s. 138-139.

50 Por. S. Nowak, Metodologia badań społecznych, Warszawa 1985, s. 25.
} 
temy twierdzeń naukowych mających status praw nauki. Współcześnie tego typu przekonanie należy uznać za błędne. Jak twierdzi Mirosław Karwat, teorię polityki możemy rozumieć również jako pewien schemat interpretacyjny:

Wyjaśnienia zjawisk z danej perspektywy mogą być częściowe, jednostronne i niekompletne, jednakże sama ta perspektywa jest spójna i konsekwentna, jeśli została oparta na wyrazistym systemie założeń opisowo-modelowych oraz definicyjnych ${ }^{51}$.

W dalszej części wywodu Karwat pisze, że za teorię polityki można uznać także podejścia definiujące jej preliminaria, a więc kwestie fundamentalne, kryteria i okoliczności uznawania zjawiska za polityczne, formy upolitycznienia.

Wydaje się, że w przypadku agonistycznej koncepcji konfliktu mamy do czynienia ze splotem dwóch zarysowanych sposobów rozumienia teorii polityki. Pierwszy z nich wskazuje bardziej na formę wywodów (sposób opisu i wyjaśnienia) oraz ich strukturę (powiązanie), ten drugi na zawartość treściową. Koncepcja Mouffe jest w obu aspektach splotem elementów filozoficznych, ideologicznych i teoretycznych, co jest nieuniknione w przypadku perspektywy ogólnej, w której wtórna jest empiryczna weryfikacja. Filozofia pozwala przemyśleć założenia metateoretyczne; ideologia uzasadnia sens wywodów i pozwala na dobór egzemplifikacji; teoria wyraża się poprzez formułowane prawidłowości, formę i strukturę analizy, propozycje do empirycznej weryfikacji. Ponieważ elementami ideologicznymi i filozoficznymi zająłem się wcześniej, omówię teraz komponenty teoretyczne.

Preliminaria w agonistycznej koncepcji Mouffe odnoszą się przede wszystkim do centralnego $\mathrm{w}$ jej schemacie interpretacyjnym rozumienia pojęcia polityczności. Jest to pojęcie ogólne, ponieważ oznacza rozmaite antagonizmy, które nie mają charakteru jednostkowego, ale przenicowują całe społeczeństwo, wpływając na pozycje i znaczenie rozmaitych zbiorowych podmiotów społecznych. Polityczność nie dotyczy również relacji powierzchownych, ale odnosi się do ontologicznego wymiaru społeczeństwa; poszczególne nieusuwalne sprzeczności stoją u podstaw sposobów, za pomocą których stanowione jest społeczeństwo ${ }^{52}$. Pojęcie polityczności wykazuje potencjał istotnościowy, ponieważ jest zdaniem Mouffe nieodzowne w zrozumieniu procesów nadawania formy i treści różnym sferom społecznym (kultura, ekonomia, sztuka, etyka itd.). Dotyczy to także samej polityki, która w tym ujęciu odnosi się do praktyk i instytucji, mających ustanowić pewien porządek i formy koegzystencji ludzi w warunkach antagonistycznych $^{53}$. Polityczność dla Mouffe nie jest więc jakąś metaforą czy zgrabnym pojęciowym wytrychem, za pomocą którego autorka chce unaocznić, iż pewne zjawiska poza sferą klasycznie rozumianej polityki ulegają upolitycznieniu. Jest wręcz odwrotnie. To właśnie istotność antagonistycznego stosunku, jakim jest polityczność, sprawia, że polityka w ogóle jest możliwa. To nie polityczność jest pochodną polityki, ale polityka wyrasta z nieusuwalnych antagonizmów w sferze polityczności, co powoduje, że zarówno polityka, jak i inne sfery życia społecznego mają konfliktowy charakter.

\footnotetext{
${ }^{51}$ M. Karwat, Rodzaje teorii w nauce o polityce, Warszawa 2011, s. 78-79.

52 Ch. Mouffe, Polityczność..., s. 23.

53 Ch. Mouffe, Paradoks demokracji..., s. 118.
} 
Należy podkreślić, że agonistyczny sposób rozumienia polityki jest dużo szerszym podejściem niż tylko koncepcja Mouffe. W ten sposób pojawia się płaszczyzna do czynienia bardziej szczegółowych porównań pomiędzy konkretnymi ujęciami agonizmu, wyłuszczania ich specyfiki i pozycjonowania jako część większej całości. Zdaniem Noëla O’Sullivana agonistyczna koncepcja polityczności odznacza się troską o podtrzymywanie (a nie zacieranie) różnic w społeczeństwie, co wiąże się w nieunikniony sposób z walką i konfliktami wokół poszukiwania sensu własnych tożsamości, sprzeciwem wobec uznanych przez państwo formatów politycznego organizowania się oraz kreowaniem alternatywnych perspektyw i form życia, w które to procesy zaangażowani są wszyscy obywatele. Wśród reprezentantów agonistycznego modelu polityczności O’Sullivan wymienia Bonnie Honig oraz Williama Connolly'ego ${ }^{54}$. Mouffe krytykuje ich podejście za to, że powtarzają błąd Hannah Arendt, zakładając pluralizm bez antagonizmu. Zdaniem Mouffe optują oni za polityczną różnorodnością, bo wierzą, że dzięki temu system nigdy nie będzie totalizującą całością. Jednakże dla Mouffe każda hegemonia oznacza choćby czasowe domknięcie, a co za tym idzie - antagonistyczne wykluczenie. Rzecz nie w tym, żeby zakłócać funkcjonowanie porządku hegemonicznego poprzez pluralizm, ale żeby kreować podstawy kontrhegemonii w oparciu o reguły ekwiwalencji, a więc łączenia przeciwstawnych wobec danego systemu żądań ${ }^{55}$.

Ważnym aspektem weryfikacji poznawczej zawartości danej koncepcji jest jej formalna strona. Chodzi mi przede wszystkim o ujęcie rozważań w formę teoretyczno-abstrakcyjnego wywodu. Prześledźmy w tym celu tok rozumowania, jaki przedstawiają w Hegemonii Mouffe i Laclau odnośnie do hegemonii politycznej. To trzon założeń ideologicznych autorów, ale ich refleksje w tym względzie zdecydowanie wykraczają poza rozumowanie ideologiczne. To raczej wykładnia rozbudowanych propozycji konceptualnych, które opierają się na systematycznym wyjaśnieniu kluczowych terminów, takich jak: dyskurs, praktyki wiązania, podmiotowość, równoważność, różnica i ostatecznie hegemonia ${ }^{56}$. Pojęcia te umożliwią następnie Mouffe zbudowanie w jej samodzielnych pracach koncepcji polityczności.

Zanurzmy się teraz w narrację Mouffe i Laclaua. Dyskurs to ustrukturyzowana całość, która jest wynikiem praktyk wiązania. Powiązanie, o którym piszą autorzy, nie odbywa się na zasadzie logicznej, transcendentnej czy esencjalnej konieczności, a przypomina raczej regularność w rozproszeniu. W obrębie dyskursu pojawiają się momenty, a więc pozycje, tożsamości, role powiązane w obrębie dyskursu. Z kolei „elementy” to różnice, które nie zostały wpisane w dyskurs. Poza dyskursem istnieje pole dyskursywności, gdzie pojawia się spora nadwyżka znaczenia. Ani pole dyskursywności nie jest do końca nieustrukturyzowane dyskursywnie, ani dyskurs nie jest do końca stabilnie zszyty. To wymiana pomiędzy nim a naporami różnych dyskursów, by obalić lub utwierdzić określone znaczenia i porządek symboliczny, decyduje o architekturze systemu — układzie

${ }^{54}$ N. O'Sullivan, Difference and the concept of the political in contemporary political philosophy, „Political Studies" XLV, 1997, nr 4, s. 744-748.

55 Ch. Mouffe, Agonistyka..., s. 24-29.

56 E. Laclau, Ch. Mouffe, op. cit., s. 111-155. 
dyskursów i w rezultacie hegemonii. Kategoria ta określa pole praktyk wiązania, a więc tam, gdzie „elementy” nie przeszły w „momenty”. Hegemonia w ten sposób rozumiana wymaga dwóch warunków: obecności antagonistycznych sił oraz nietrwałości oddzielających je granic.

Jedynie obecność rozległego obszaru swobodnych elementów wraz z możliwością ich powiązania z przeciwnymi obszarami, co pociąga za sobą konieczność ich ciągłego redefiniowania, przygotowuje grunt pod uznanie praktyki za hegemoniczną ${ }^{57}$.

Wywody prowadzone na takim poziomie abstrakcji mogą oczywiście sprawiać wrażenie zbyt spekulacyjnych; jak w każdym przypadku mogą być też odrzucane przez badaczy. Trudno jednak zaprzeczyć, że nawet jeżeli wyrastają z ideologicznych przesłanek, są podawane za pomocą pojęć wyrastających z jawnie artykułowanych procesów operacjonalizacji i teoretycznej autorefleksji, a tym samym sposób ich prezentacji nie jest dogmatyczny, a merytoryczny.

Wartość danej teorii naukowej podkreśla również zakres jej aplikacji w dyskursie naukowym. Taka obecność wprawdzie nie zastąpi badań empirycznych w weryfikacji założeń teoretycznych, ale może stanowić ich zaczyn. Mouffe podkreśla w Agonistyce, że jej koncepcja narodziła się z refleksji nad demokracją liberalną, ale z czasem zatoczyła ona szeroki krąg ${ }^{58}$. W kolejnych rozwinięciach swojej perspektywy Mouffe przechodziła od rozważań spekulatywnych do analizy niemal wszystkich istotnych problemów politycznych. W ten sposób abstrakcyjna koncepcja zyskiwała wiele egzemplifikacji, które można postrzegać jako hipotezy możliwe do przetestowania w badaniach empirycznych. W książce Polityczność zajęła się prawicowym populizmem i terroryzmem. I w tym przypadku sugerowała, że radykalny sprzeciw polityczny jest zawsze wyrazem zablokowania pluralistycznej polityki. Tylko realnie agonistyczna polityka uwzględniająca rzeczywiste antagonizmy społeczne, zarówno w skali poszczególnych państw, jak i na arenie międzynarodowej, może ujawnić sprzeczności, które zablokował porządek neoliberalny w imię racjonalnego równoważenia racji ${ }^{59}$. Również inni badacze wykorzystali te tropy w swoich interpretacjach zjawiska populizmu europejskiego ${ }^{60}$. Natomiast w Agonistyce Mouffe nie zajmowała się już tylko wyjaśnianiem zjawisk negatywnych we współczesnym świecie, ale chciała przemyśleć możliwość kontrhegemonicznej polityki uwzględniającej różne wymiary rzeczywistości (stosunki międzynarodowe, polityka europejska, praktyki artystyczne). W przypadku polityki europejskiej Mouffe, z jednej strony, opowiedziała się za unią federalną zabezpieczającą różne państwa przed koniecznością samodzielnego sprostania problemom $\mathrm{w}$ turbulentnych czasach globalizacji. Z drugiej strony, zdecydowanie sprzeciwiła się tworzeniu jakiegoś homogenicznego narodu europejskiego, który unieważniałby „my” narodowe. $\mathrm{Z}$ tego też powodu, analizując politykę gospodarczą

57 Ibidem, s. 146.

58 Ch. Mouffe, Agonistyka..., s. 33.

59 Ch. Mouffe, Polityczność..., s. 82-85, 93-99.

60 F. Biały, Konflikt jako wartość? Demokracja agonistyczna a populizm europejski w ujęciu Chantal Mouffe, „Refleksje” 2010, nr 1, s. 219-233. 
Unii Europejskiej, opowiedziała się przeciwko ideologii wolnego handlu, a za uwzględnieniem perspektywy regionalnej ${ }^{61}$.

Aplikacyjność koncepcji polityczności, agonizmu i dyskursu nie kończy się na samych pracach Mouffe i Laclaua. W ostatnich latach pojawiło się sporo odniesień do ich podejścia przy okazji weryfikacji różnych problemów naukowych. Niektórzy podjęli się nawet trudu zaproponowania rozmaitych metod empirycznych, które pozwoliłyby wyjść poza posługiwanie się omawianą koncepcją według z góry powziętych założeń. Wiktor Marzec uznał, że interesujące w tym względzie byłoby powiązanie koncepcji Mouffe i Laclaua z Krytyczną Analizą Dyskursu oraz wspomaganymi komputerowo metodami leksykometrycznymi ${ }^{62}$.

Bodaj najbardziej szeroko, poza teorią i filozofią polityki, możemy odnaleźć agonistyczny koncept polityczności w ramach tzw. studiów kulturowych ${ }^{63}$. I w tym przypadku niezwykle istotne okazuje się pojęcie hegemonii, a kultura, $\mathrm{w}$ tym kultura popularna, jak konstatuje John Storey, ma w swej istocie znaczenie polityczne, gdyż jest strukturą generującą konflikty, spory, kontrowersje. To dla studiów kulturowych główne miejsce walki ideologicznej, teren „inkorporacji” i „sprzeciwu”, jedna z tych sfer, gdzie można zdobyć hegemonię lub ją utracić ${ }^{64}$. Szczególnie interesującym poznawczo zagadnieniem w tym względzie jest problem polityczności sztuki. Za przykład mogą służyć moje własne badania nad politycznością filmu, z których wynika, że realizacja filmów, ich odbiór przez widzów oraz rozmaite interpretacje dokonywane przez krytyków są częścią debaty, a czasami wręcz walki o obowiązujące w przestrzeni publicznej znaczenia, kształt naszych wartości, sposób postrzegania tego, co obiektywne. Sens tych treści odczytywać należy w ramach konkretnych skonfliktowanych względem siebie dyskursów ${ }^{65}$.

W ostatnich latach zaczęto zastanawiać się również, czy radykalna demokracja agonistyczna jest możliwa w czasach naporu nowych technologii. W ten sposób pojawiły się projekty tzw. radykalnej e-demokracji ${ }^{66}$. Jednym $\mathrm{z}$ najważniejszych przedstawicieli tego nurtu jest Lincoln Dahlberg, który uważa, że Internet należy przede wszystkim postrzegać jako przestrzeń sporną opartą na relacjach włączania i wykluczania. Badacze $\mathrm{z}$ tego nurtu dostrzegają znaczenie Internetu w kreowaniu krytycznej opinii i krytycznych dyskursów, które mogą się wyrażać w zupełnie niezależnych od władzy kanałach (np. Indymedia). Ważne okazują się także różne formy bezpośrednich akcji politycznych w Internecie (tzw. haktywizm) ${ }^{67}$.

${ }^{61}$ Ch. Mouffe, Agonistyka..., s. 71.

62 W. Marzec, op. cit., s. 188 n.

63 Zob. na ten temat: Ch. Barker, Studia kulturowe - teoria i praktyka, Kraków 2005, s. 119-120.

64 J. Storey, Studia kulturowe i badania kultury popularnej. Teorie i metody, Kraków 2003, s. 12.

65 K. Minkner, O filmach politycznych. Między polityką, politycznością i ideologią, Warszawa 2012, s. 199 n.

${ }^{66}$ Radical Democracy and the Internet Interrogating Theory and Practice, red. L. Dahlberg, E. Siapera, New York 2007. Szerzej piszę na ten temat w: K. Minkner, The Internet and the Agonistic Understanding of the Political: Theoretical Reflexions in the Context of Radical e-Democracy, [w:] Open Europe: Cultural Dialogue Across Borders. Europe of the Wary: New Communication and Information Order for Reduction of Tension within the United Europe, red. W. Piątkowska-Stepaniak, Opole 2014, s. 129-141.

67 L. Dahlberg, Re-constructing digital democracy: An outline of four „positions”, „New Media Society” 2011, $\mathrm{nr} 13$ (6), s. 855-872. 


\section{Dyskursywny charakter koncepcji polityczności Mouffe}

Kolejnym kryterium, które pozwala odnieść się do wartości poznawczej danej koncepcji, jest jej dyskursywny potencjał. Oznacza to, że dane podejście nie zamyka się wyłącznie w przestrzeni ideologicznych dogmatów, potwierdzających je teorii i egzemplifikacji, ale kształtuje się w obrębie pluralistycznej debaty intelektualnej. Rozpatrzmy dwa przypadki.

Po pierwsze, można odnosić daną koncepcję naukową do innych podejść, teorii, ujęć, które prezentują odmienny (czasami bezpośrednio krytyczny) punkt widzenia odnośnie do danego zagadnienia i wzajemnie. W ten sposób tworzy się możliwość głębszej weryfikacji twierdzeń teoretycznych. Przykład może stanowić polemika Mouffe i rzeczników deliberacyjnego modelu demokracji. Zdaniem reprezentantów tego drugiego podejścia możliwy jest do osiągnięcia ogólny konsensus w sferze publicznej, a w rezultacie efektywna legitymizacja systemu, jeżeli poszczególni uczestnicy procesu deliberacji zastosują procedury publicznej wymiany argumentów oparte na racjonalności i bezstronności, a wszyscy, których decyzje dotyczą, będą mogli wziąć udział w deliberacji bezpośrednio albo poprzez swoich przedstawicieli ${ }^{68}$. Mouffe spierała się przede wszystkim z dwoma reprezentantami tego ujęcia - Jürgenem Habermasem oraz Johnem Rawlsem. Zdaniem Mouffe demokracja deliberacyjna uwydatnia konflikty, by je ostatecznie znieść na płaszczyźnie wspólnoty politycznej, spychając to, co różne, do sfery jednostkowej, a więc rzekomo odpolitycznionej. Mouffe nie wierzy także w możliwość wypraktykowania bezstronnych racjonalnych procedur deliberacyjnych ${ }^{69}$. Obrońcy deliberacyjnego modelu nie pozostają dłużni. Przykładowo, Eva Erman uważa, że deliberacja wcale nie wyklucza agonizmu, a nawet antagonizmu. Nie zgadza się z Mouffe, że antagonizm nie odbywa się we wspólnej przestrzeni symbolicznej. Jej zdaniem nawet jeżeli strony stosunku antagonistycznego nie podzielają żadnych idei czy wartości, ale rozpoznają się jako wrogowie, to musi to wynikać z istnienia jakiejś wspólnej sfery symbolicznej, w której podmioty te funkcjonują. I właśnie dlatego deliberacja jest nie tylko możliwa, ale to ona stanowi warunek konstytutywny antagonizmu ${ }^{70}$. W ostatnim czasie coraz częściej pojawia się też tendencja do łączenia obu perspektyw i podkreślania, że nie jest możliwy wybór, które podejście jest bardziej adekwatne, ponieważ są one tak naprawdę komplementarne. Kei Yamamoto twierdzi, że jeżeli uznajemy jakieś minimalne warunki dla konfliktów w procesie deliberacji, to nie możemy odrzucać konsensusu, jaki z tego wynika ${ }^{71}$.

Należy odnotować, że polemiki występują również pomiędzy badaczami z tego samego obozu intelektualnego i ideowego. Tak jest chociażby w przypadku różnic między koncepcją agonistyczną a ujęciem innego postmarksisty, Slavoja Žižka. Stawia on ago-

68 Deliberative Democracy and Its Discontents, red. S. Besson, J.L. Martí, Aldershot 2006, s. XV-XVI.

69 Polemika Mouffe z przedstawicielami agregacyjnego, a przede wszystkim deliberacyjnego modelu demokracji znajduje się w: Ch. Mouffe, Paradoks demokracji..., s. 98-115.

70 E. Erman, What is wrong with agonistic pluralism? Reflections on conflict in democratic theory, „Philosophy and Social Criticism" 35, 2009, nr 9, s. 1039-1062.

$71 \mathrm{~K}$. Yamamoto, Beyond the dichotomy of agonism and deliberation: The impasse of contemporary democratic theory, „Multicultural Studies” 11, 2011, s. 176-177, http://hdl.handle.net/2237/14652 (dostęp: 1 października 2016). 
nistom zarzut zbytniej dywersyfikacji antagonizmów. Powoduje to brak możliwości zogniskowania się wokół kluczowych kryteriów i wytyczenia na tej podstawie osi jednego fundamentalnego sporu pomiędzy blokiem hegemonicznym a kontrhegemonicznym. Dla Žižka konflikt tego typu ma charakter traumatyczny, bo funkcjonuje poza logiką systemu. Oznacza to, iż jedna grupa, kompletnie dotąd wyłączona i niefunkcjonująca w życiu publicznym, wychodzi ze swoją chęcią uczestnictwa w sferze publicznej; z jednej strony, zmusza to władzę do podziału, z drugiej - ukazuje niekompletność ideologii. Żeby było to możliwe, nie należy ani funkcjonować $\mathrm{w}$ ramach typowych partii politycznych, bo gra się wówczas w karty systemu, ani „rozmieniać się na drobne” w ramach różnych grup emancypacyjnych. Należy raczej zjednoczyć wszystkie antysystemowe siły pod egidą jednej partii politycznej i zmusić system do ustępstw w stosunku do samych reguł gry ${ }^{72}$. Mouffe nie zgadza się z Žižkiem, że demokratyczny agonizm wspiera status $q u o$, i odpowiada, że konieczne jest narzucenie kontrhegemonicznego rozumienia demokracji będące zaczynem jej radykalnego pogłębienia ${ }^{73}$.

Drugi aspekt dyskursywności danego podejścia oznacza, że w jego ramach pojawiają się zapożyczenia z ujęć, które zarówno ideologicznie, jak i paradygmatycznie pochodzą z odmiennych środowisk. To szczególnie interesująca sposobność do odsłaniania specyfiki danej koncepcji.

Bodaj najbardziej znamiennym pod tym względem wyborem jest sięgnięcie przez Mouffe do pism prawicowego Carla Schmitta. Mouffe zgadza się ze Schmittem, że polityczność ma konfliktową naturę i naznaczona jest przez nieusuwalny antagonistyczny stosunek przyjaciel-wróg. Jak twierdzi, spostrzeżenia Schmitta są jej potrzebne, żeby uzmysłowić sobie, że prawidłowość ta zachowuje swoje znaczenie również w czasach demokracji liberalnej. Jej zdaniem Schmitt nie dostrzegał jednak możliwości przejścia antagonizmu w agonizm w obrębie demokracji liberalnej, ponieważ odrzucał ten model. Wskazywał również na to, że liberalizm prowadzić może do odpolitycznienia wspólnoty, a demokracja do pseudoupolitycznienia różnych problemów ${ }^{74}$. Dla Mouffe wszystkie te tropy są bliskie, ale jednocześnie odrzuca ona konkluzje Schmitta; chce myśleć wraz z nim, ale jednocześnie przeciwko niemu. Dostrzega możliwość krytyki obecnego modelu neoliberalnego opartego na uniwersalistycznych i indywidualistycznych założeniach, ale zarazem nie chce wybierać pomiędzy demokracją i liberalizmem, uznając wartość obu tych składowych ${ }^{75}$.

Interesujące są również nawiązania Mouffe do pism konserwatysty brytyjskiego Michaela Oakeshotta. Jego koncepcja polityki jest podobnie paradoksalna, jak u Mouffe. W obu przypadkach krytykuje się racjonalizm po to, by usankcjonować demokratyczne praktyki. U Oakeshotta chodzi o obronę konserwatyzmu, a u agonistów o odrodzenie lewicy. Logika rozumowania jest jednak podobna. Mouffe zgadza się z Oakeshottem, że dla legitymizacji instytucji politycznych nie jest potrzebna wyobrażona, racjonali-

72 Spór Žižka z Mouffe i Laclauem jest zrelacjonowany np. w: P. Dybel, S. Wróbel, Granice polityczności, Warszawa 2008, s. 310-320.

73 Ch. Mouffe, Polityczność..., s. 48.

74 C. Schmitt, op. cit., s. 195.

75 Ch. Mouffe, Wyzwanie Schmitta..., s. 5-11. 
stycznie uzasadniana aprobata, a stałe wsparcie oparte na działaniach. Mouffe docenia w koncepcji Oakeshotta sceptycyzm poznawczy, który opiera się na empiriokrytycznych twierdzeniach, iż w rzeczywistości społecznej niczego tak naprawdę nie możemy być pewni, bo brakuje nam jakichś transcendentnych punktów oparcia w porządku naturalnym czy ponadnaturalnym. I właśnie dlatego, zdaniem Oakeshotta, najbardziej adekwatna w polityce jest postawa konserwatywna; nie należy odgórnie narzucać jakichś innowacyjnych wizji, ponieważ tradycja to jedyne, co jest sprawdzone i przez to bezpieczne dla społeczeństwa ${ }^{76}$. Mouffe nie akceptuje oczywiście konserwatywnych wniosków Oakeshotta, ale przeprowadza podobną operację intelektualną, by agoniczny konflikt odbywał się zgodnie z regułami porządku demokratycznego. Jej zdaniem należy przede wszystkim oddzielić tradycjonalizm i tradycję. To pierwsze pojęcie oznacza, iż tradycja jest w istocie rzeczy serią naturalnych i koniecznych zjawisk. Tymczasem należy dokonać dekonstrukcji tradycji i postrzegać ją jako przygodny konstrukt. Tradycja tak pojmowana pozwala nam zrozumieć, że jesteśmy konstruowani jako podmioty dzięki już istniejącym dyskursom, które umożliwiają nam działalność w świecie ${ }^{77}$.

Sądzę, że uwypuklanie nawiązań do Schmitta czy Oakeshotta, a więc do badaczy z zupełnie odmiennych środowisk politycznych, pozwala spojrzeć na propozycje teoretyczne Mouffe i Laclaua szerzej niż tylko przez ideologiczny pryzmat ich własnych celów. Poza tym, tak jak Mouffe i Laclau przepracowali Schmitta, ich własna koncepcja może stanowić podstawę do przemyślenia teorii polityki dla rozmaitych, bynajmniej nie tylko lewicowych, środowisk politycznych ${ }^{78}$.

\section{Podsumowanie}

Na podstawie przeprowadzonych analiz można orzec, iż agonistyczna koncepcja konfliktu politycznego Chantal Mouffe spełnia wszelkie kryteria perspektywy naukowej o wysokim potencjale poznawczym. W artykule swoim nie chciałem jednak naiwnie twierdzić, że potencjał ów przeważa nad ideologicznym albo że go unieważnia. Starałem się raczej dowieść, że koncepcja agonistyczna jest przykładem teorii, w ramach której komponenty ideologiczne wręcz współtworzą jej zawartość naukową. Ważniejsza jednak refleksja wynika nie tyle z odnotowanej tu konkluzji, ile z samej wartości pochylania się nad ideologicznością teorii naukowych, dzięki czemu można lepiej zrozumieć walory poznawcze komponentów ideologicznych.

Wywody, które zaprezentowałem, skłaniają do zaproponowania kilku kryteriów mierzenia wartości naukowej koncepcji ideologicznie uwikłanych. Uznałem, że do tych celów najlepiej służy optyka metateoretyczna, która pozwala uniknąć referowania danej koncepcji na rzecz problemowej i formalnej analizy jej uwarunkowań, uwikłań, treści

76 M. Oakeshott, Wieża Babel i inne eseje, Warszawa 1999, s. 206-217.

77 Ch. Mouffe, The Return of the Political..., s. 16.

78 Przykładem wykorzystania przez prawicowych intelektualistów konceptów lewicowych może być zastosowanie teorii hegemonii kulturowej Gramsciego przez ideologa francuskiej tzw. Nowej Prawicy, Alaina de Benoista. Zob. szerzej: T. Bar-On, Where Have All the Fascists Gone?, Aldershot 2007, s. 35 n. 
oraz relacji z innymi podejściami. W moim przekonaniu rozważania tego typu powinny odbywać się na trzech płaszczyznach. Po pierwsze, poprzez pogłębioną analizę ontologicznych i epistemologicznych założeń. Po drugie, poprzez wiwisekcję statusu poznawczego danej koncepcji, która obejmuje strukturę i formę wywodów, a także aplikacyjność. Po trzecie, poprzez analizę debat naukowych, w których zanurzona jest badana koncepcja. Jednocześnie uważam, że kryteria te można także zastosować, żeby przetestować ideologiczność koncepcji pozornie neutralnych.

Ogólne wnioski, jakie płyną z przeprowadzonych wywodów, pozwalają stwierdzić, że zgłębianie koncepcji uwikłanych ideologicznie może być interesującym przyczynkiem do badania problemu obiektywności nauk politycznych. Propagatorzy agonizmu nie mamią nas przeźroczystą neutralnością swoich dociekań, nie ukrywają naukowej i politycznej stronniczości, ale tematyzują paradygmatyczne przesłanki swojego myślenia. Taka postawa nie tylko wydaje się uczciwa naukowo, ale paradoksalnie może wzmacniać naukowy obiektywizm. Pełna neutralność jest w naukach politycznych i tak niemożliwa, ale filozoficzna w swej istocie (samo)świadomość rozmaitych stanowisk ontologicznych i aksjologicznych oraz zadeklarowanie własnego poglądu pozwala na intersubiektywne uzgadnianie prawdy ${ }^{79}$.

\section{Bibliografia}

Barker Ch., Studia kulturowe - teoria i praktyka, Wydawnictwo Uniwersytetu Jagiellońskiego, Kraków 2005.

Bar-On T., Where Have All the Fascists Gone?, Ashagate, Aldershot 2007.

Berberoglu B., An Introduction to Classical and Contemporary Social Theory: A Critical Perspective, Rowman \& Littlefield Publishing, Oxford 2005.

Biały F., Konflikt jako wartość? Demokracja agonistyczna a populizm europejski w ujęciu Chantal Mouffe, „Refleksje” 2010, nr 1, s. 219-233.

Buksiński T., Wspótczesne filozofie polityki, Uniwersytet im. Adama Mickiewicza w Poznaniu, Wydawnictwo Naukowe Instytutu Filozofii, Poznań 2006.

Carl Schmitt. Wyzwanie polityczności, red. Ch. Mouffe, Wydawnictwo Krytyki Politycznej, Warszawa 2011.

Dahlberg L., Re-constructing digital democracy: An outline of four "positions”, „New Media Society” 2011, nr 13 (6), s. 855-872.

Deliberative Democracy and Its Discontents, red. S. Besson, J.L. Martí, Ashgate, Aldershot 2006.

Derrida J., Marginesy filozofi, Wydawnictwo KR, Warszawa 2002.

Derrida J., O gramatologii, Wydawnictwo Officyna, Łódź 2011.

Discourse Theory and Political Analysis: Identities, Hegemonies and Social Change, red. D. Howarth, A.J. Norval, Y. Stavrakakis, Manchester University Press, Manchester 2000.

Dybel P., Wróbel S., Granice polityczności, Aletheia, Warszawa 2008.

Erman E., What is wrong with agonistic pluralism? Reflections on conflict in democratic theory, „Philosophy and Social Criticism" 35, 2009, nr 9, s. 1039-1062.

Goldstein P., Post-Marxist Theory: An Introduction, State University of New York Press, New York 2005.

Gramsci A., Nowoczesny książe, Studenckie Koło Filozofii Marksistowskiej UW, Warszawa 2006 [wydanie opracowane na podstawie: A. Gramsci, Pisma wybrane, t. 1, Książka i Wiedza, Warszawa 1961].

79 Zob. szerzej: L. Rubisz, Neutralność jako kryterium naukowości politologii, [w:] Podejścia badawcze i metodologiczne w nauce o polityce, red. B. Krauz-Mozer, P. Ścigaj, Kraków 2013, s. 163-184. 
Gramsci A., Zeszyty filozoficzne, Wydawnictwo Naukowe PWN, Warszawa 1991.

Karwat M., Metawiedza, esencja, forma, pragmatyka - cztery płaszczyzny badań teoriopolitycznych, [w:] Podejścia badawcze i metodologie w nauce o polityce, red. B. Krauz-Mozer, P. Ścigaj, Wydawnnictwo Księgarnia Akademicka, Kraków 2013, s. 45-72.

Karwat M., Rodzaje teorii w nauce o polityce, [w:] Czym jest teoria w politologii?, red. Z. Blok, DW Elipsa, Warszawa 2011, s. 75-93.

Laclau E., Deconstruction, Pragmatism, Hegemony, [w:] Deconstruction and Pragmatism, red. Ch. Mouffe, Routledge, New York 2005, s. 49-70.

Laclau E., Dyskurs, [w:] Przewodnik po wspótczesnej filozofii politycznej, red. R.E. Godin, F. Petit, Książka i Wiedza, Warszawa 2002, s. 555-562.

Laclau E., Mouffe Ch., Hegemonia i socjalistyczna strategia. Przyczynek do projektu radykalnej polityki demokratycznej, Wydawnictwo Naukowe Dolnośląskiej Szkoły Wyższej Edukacji TWP we Wrocławiu, Wrocław 2007.

Ludzie potrzebuja alternatywy. Z Chantal Mouffe i Ernesto Laclauem rozmawiaja Maciej Gdula, Julian Kutyła $i$ Adam Ostolski, http://www.krytykapolityczna.pl/Nr7-82005/Ludziepotrzebujaalternatywy/menuid-1.html (dostęp: 2 października 2016).

Marsh D., Furlong P., Skóra, a nie sweter: ontologia i epistemologia w politologii, [w:] Teorie i metody w naukach politycznych, red. D. Marsh, G. Stoker, Wydawnictwo Uniwersytetu Jagiellońskiego, Kraków 2006, s. $17-40$.

Marzec W., Poststrukturalistyczna teoria dyskursu i empiryczne badania społeczne, „Praktyka Teoretyczna” 2011, nr 4, s. 185-198.

Melosik Z., Poststrukturalizm jako teoria życia społecznego (możliwości i kontrowersje), „Kultura Współczesna" 1997, nr 1, s. 57-71.

Minkner K., Główne problemy konceptualizacji pojęcia polityczności, „Studia Politologiczne” 37, 2015, s. 50-74.

Minkner K., The Internet and the Agonistic Understanding of the Political: Theoretical Reflexions in the Context of Radical e-Democracy, [w:] Open Europe: Cultural Dialogue Across Borders. Europe of the Wary: New Communication and Information Order for Reduction of Tension within the United Europe, red. W. Piątkowska-Stepaniak, Wydawnictwo Uniwersytetu Opolskiego, Opole 2014, s. 129-141.

Minkner K., O filmach politycznych. Między polityką, politycznością i ideologią, DW Elipsa, Warszawa 2012.

Minkner K., Tradycyjny instytucjonalizm i jego znaczenie dla nauk politycznych, „Historia i Polityka” 2015, nr 13, s. 9-29.

Morawski K., „Niemożliwość społeczeństwa”. Analiza postmarksistowskiego stanowiska Ernesta Laclaua, „Zeszyty Naukowe Towarzystwa Doktorantów UJ. Nauki Humanistyczne, Kierunki badawcze w filozofii" II, 2011, nr 3, s. 19-31.

Mouffe Ch., Agonistyka. Polityczne myślenie o świecie, Wydawnictwo Krytyki Politycznej, Warszawa 2015.

Mouffe Ch., Paradoks demokracji, Wydawnictwo Naukowe Dolnośląskiej Szkoły Wyższej Edukacji TWP we Wrocławiu, Wrocław 2005.

Mouffe Ch., Polityczność. Przewodnik Krytyki Politycznej, Wydawnictwo Krytyki Politycznej, Warszawa 2008.

Mouffe Ch., Radical democracy: modern or postmodern?, „Social Text” 1989, nr 21, s. 31-45.

Mouffe Ch., The Return of the Political, Verso, London-New York 1993.

Mouffe Ch., Wyzwanie Schmitta, [w:] Carl Schmitt. Wyzwanie polityczności, red. eadem, Wydawnictwo Krytyki Politycznej, Warszawa 2011.

Mucha J., Konflikt i społeczeństwo. Z problematyki konfliktu społecznego we współczesnych teoriach zachodnich, Państwowe Wydawnictwo Naukowe, Warszawa 1978.

Nowak S., Metodologia badań społecznych, Państwowe Wydawnictwo Naukowe, Warszawa 1985.

Oakeshott M., Wieża Babel i inne eseje, Aletheia, Warszawa 1999.

O'Sullivan N., Difference and the concept of the political in contemporary political philosophy, „Political Studies" XLV, 1997, nr 4, s. 739-754.

Pels D., Property and Power in Social Theory: A Study in Intellectual Rivalry, Routledge, London-New York 1998.

Wrocławskie Studia Politologiczne 22, 2017

(C) for this edition by CNS 
Przyłęcki P., Założenia teorii dyskursu Ernesta Laclaua i Chantal Mouffe, „Przegląd Socjologiczny” 2013, nr 4, s. 9-24.

Radical Democracy and the Internet Interrogating Theory and Practice, red. L. Dahlberg, E. Siapera, Palgrave Macmillan, New York 2007.

Rasiński L., Dyskursywna koncepcja władzy. Foucault i Laclau o dyskursie, podmiocie i władzy, „Principia” LIII, 2010, s. 177-192.

Rubisz L., Neutralność jako kryterium naukowości politologii, [w:] Podejścia badawcze i metodologie w nauce o polityce, red. B. Krauz-Mozer, P. Ścigaj, Wydawnnictwo: Księgarnia Akademicka, Kraków 2013, s. $163-184$.

Salamini L., The Sociology of Political Praxis: An Introduction to Gramsci's Theory, Routledge, London-New York 2014.

Schmitt C., Teologia polityczna i inne pisma, Społeczny Instytut Wydawniczy Znak, Kraków 2000.

Sim S., Post-Marxism. An intellectual history, Taylor \& Francis e-Library, London-New York 2001.

Storey J., Studia kulturowe i badania kultury popularnej. Teorie i metody, Wydawnictwo Uniwersytetu Jagiellońskiego, Kraków 2003.

Topolski J., Linguistic turn w historiografii. Ze współczesnej filozofii humanistyki, „Studia Politologiczne” 8, 2004, s. 217-233.

Turner J.H., Struktura teorii socjologicznej. Wydanie nowe, PWN, Warszawa 2004.

Yamamoto K., Beyond the dichotomy of agonism and deliberation: The impasse of contemporary democratic theory, „Multicultural Studies” 11, 2011, s. 176-177, http://hdl.handle.net/2237/14652 (dostęp: 1 października 2016).

\section{Metatheoretical comments on Chantal Mouffe's conception of the political in the context of its ideological implications}

Keywords: the political, agonism, discourse, conflict theory, metatheory

\section{Summary}

The article contains the thesis that in political science theories a scientific, ideological and philosophical components are so fused that it is impossible to separate them completely. For this reason, the ideological content not only does not undermine the cognitive value of theoretical argument, but even contributes to it - if the relevant criteria are met. I think, that the metatheoretical optics is the most appropriate approach to analyse these criteria. It allows not only to describe given theory, but also enables more problematic deconstruction of its conditions and cognitive status. In this article the analysis of this type is presented on the example of Chantal Mouffe's agonistic conflict theory by taking into consideration three following criteria. First, the ontological and epistemological assumptions of this theory are explained. Secondly, vivisection of the structures and forms of reasoning peculiar to the agonistic paradigm is conducted, followed by the examination of the paradigm's presence in the scientific discourse. Thirdly, the approaches which are both polemical and supportive for the Mouffe's theory, but representing different intellectual and ideological circles, are presented. 